\title{
Legal Aspects of Conflict-Induced Migration by Women
}

\author{
Audrey Macklin
}

\begin{abstract}
This paper surveys the international legal frameworks, including the many guidelines, handbooks, resolutions, toolkits, conclusions and manuals produced by various United Nations bodies, that confirm an awareness of the protection issues specific to women and girls displaced by conflict. It explores the extent to which these documents address the gendered impacts of conflict-induced migration, and the role of United Nations bodies as international governmental organisations in implementing these norms. The main focus is upon internally displaced women and women refugees. In addition to problems of enforcing compliance with existing guidelines, the paper concludes that two areas - developing strategies to accommodate the realities of long-term, even permanent displacement and enhancing women's literal and legal literacy - require much greater attention on the part of governmental and non-governmental international organisations.

A2008 Reproductive Health Matters. All rights reserved.
\end{abstract}

Keywords: internally displaced persons, gender issues, refugees, conflict and crisis settings, international law, United Nations

P

EOPLE migrate to avoid anticipated conflict, to flee ongoing conflict and to escape the consequences of past conflict. The capacity to migrate and the migratory experience itself are inflected by gender. The purpose of this paper is to survey how international legal norms and institutions frame and respond to conflict-induced migration, with particular attention to the impact of gender on access to legal status and protection. ${ }^{1}$

In conflict situations, women and girls tend to be less mobile then their male cohorts. Constraints include responsibility for children, elderly or disabled kin, and/or safety, cultural and financial obstacles to travel without male accompaniment. The majority of the world's forcibly displaced population remains within state borders, and the majority of this population is also female.

If a woman flees ongoing or impending conflict but remains within the geo-political borders of a state, her migration is described as internal displacement, and she is labelled an internally displaced person (IDP). If she crosses an interna- tional border into a neighbouring country that is a party to the 1951 UN Convention Relating to the Status of Refugees and/or the 1967 Protocol, she may qualify as a refugee. Other regional instruments may also offer refugee protection. More rarely, she may journey further afield, even to one of the industrialised states of the global North. Depending on how she travels, she may be categorised as a resettled refugee, an asylum seeker, a smuggled or trafficked person, or a non-status ("illegal") migrant. Apart from refugee protection and the prohibition on the return of persons to face a substantial risk of torture under Article 8 of the Convention Against Torture, international law imposes few restraints on the expulsion of non-citizens. ${ }^{2}$

The nexus between armed conflict and violations of women's and girls' human rights is addressed by UN Security Council Resolution 1325. ${ }^{3}$ The Resolution exhorts Member states, parties to armed conflict, military and civilian personnel of peacekeeping missions, and other actors to attend to the specific vulnerabilities and needs of women and girls in armed conflict, 
and to incorporate a gender perspective (and more women) into all phases of activity, including training, programming and field operations. Importantly, Article 1 of Resolution 1325 also "urges Member States to ensure increased representation of women at all decision-making levels in national, regional and international institutes and mechanisms for the prevention, management and resolution of conflict". Other provisions emphasise the importance of "involving women in all peacekeeping and peacebuilding measures" (Article 6) and the need for "measures that support local women's peace initiatives and indigenous processes for conflict resolution, and that involve women in all of the implementation of the peace agreements (Article 8(b)). The dual emphases on substantive protection of women and girls' human rights and the imperative of including women in decision-making and governance processes at all stages and levels, is mirrored in various initiatives specific to women and conflict-induced migration.

The gender-specific social, economic, familial, sexual, physical and medical impacts associated with conflict-induced migration have been documented by scholars, activists, and international governmental and non-governmental organisations. A recent United Nations High Commissioner for Refugees (UNHCR) report usefully summarises the major human rights risks and vulnerabilities for women and girls:

a) ...birth registration or documentation problems, resulting in a lack of legal identity, which can mean women and girls in particular are vulnerable, for instance, to exclusion from access to resources, to trafficking, to statelessness and/or are unable to pass on nationality to their children;

b) ...lack of age and sex disaggregated data, which prevents adequate identification of groups with specific protection needs;

c) camp management, community and leadership structures are insufficiently inclusive of women and gender power relations are unequal;

d) ... food and other shortages, resulting in women's and girls' exposure to prostitution, sexual harassment and trafficking, malnutrition, increased drop-out from schools for girls, and child labour;

e) health services, including female-to-female services, are not sufficiently accessible, especially bearing in mind that women's sexual and reproductive roles place them at particular risk during pregnancy and giving birth, and that they are disproportionately vulnerable to HIVIAIDS;

f) functioning justice systems are not in place or, where they are, traditional harmful practices, domestic violence and other crimes are not adequately addressed; and

g) return and reintegration are hampered, for instance, by discriminatory property and inheritance laws. ${ }^{4}$

This paper focuses on the international legal frameworks related to migration, the extent to which they address these impacts, and the role of United Nations bodies (qua international governmental organisations) in implementing these norms. It is important to acknowledge that while armed conflict and displacement trigger a range of human rights violations by hostile forces, women displaced by conflict are also at heightened risk of domestic violence, coerced sex, harmful cultural practices, unequal access to resources and social exclusion from members of their own families and communities. Conflict and displacement do not create the structural inequality that underwrites systemic violations of women's human rights, although both phenomena can and do exacerbate the manifestations of that inequality.

\section{Internal displacement}

\section{Normative framework}

The UN Guiding Principles on Internal Displacement (hereafter IDP Guiding Principles) defines its subject matter as:

"...persons or groups of persons who have been forced or obliged to flee or to leave their homes or places of habitual residence, in particular as a result of or in order to avoid the effects of armed conflict, situations of generalised violence, violations of human rights or natural or human-made disasters, and who have not crossed an internationally recognised State border. ${ }^{5}$

In brief, internally displaced persons (IDPs) are forced migrants located within the borders of their state of nationality. IDPs may remain in their home state for a variety of reasons, including the following: a desire to stay as close to their homes as possible; the presence of kin or 
friends within the state who can provide assistance (often precarious); lack of resources to reach an international border; and/or obstacles to entry erected by adjacent states. Although international actors acknowledge the right to exit one's country and to seek and enjoy asylum, efforts are sometimes made to discourage flight by offering some form of international protection (in so-called safe havens or other designated areas) within the territory of the state. The success of these initiatives is notoriously uneven and they remain controversial.

The term IDP is descriptive and sociological. It does not designate a status recognised in international law, and does not confer specific or unique rights. (In contrast, refugee status entails a legal right against refoulement, or forced relocation to place of origin.) In the context of conflict-induced migration, the trauma, experiences and needs of IDPs may render them indistinguishable from refugees. However, two important differences warrant emphasis: first, the IDP definition encompasses a broader range of causal factors (e.g. development or disasterinduced displacement) than does the UN refugee definition (which is limited to persecution on stipulated grounds). Secondly, the fact that IDPs have not crossed a border means that their own state may directly or indirectly create the conditions leading to displacement, while invoking the principle of state sovereignty to deflect external intervention or criticism of its failure to protect its citizenry. Francis Deng and Roberta Cohen provide a pithy rejoinder to this disingenuous assertion of state sovereignty through the concept of "sovereignty as responsibility":

"The concept of sovereignty cannot be dissociated from responsibility: a state should not be able to claim the prerogatives of sovereignty unless it carries out its internationally recognized responsibilities to its citizens." ${ }^{\prime 6}$

The IDP Guiding Principles are known as "soft law" because they do not in themselves create binding legal obligation on states. In spite of or because of that fact, the IDP Guiding Principles have attracted broad support and endorsement since their formulation. The IDP Guiding Principles set out standards relating to protection of IDPs and the provision of humanitarian assistance. To the extent that humanitarian assistance may be a material means of fulfilling protection objectives, protection and humanitarian assistance may overlap in operational terms. Nevertheless, a recent study argues for the importance of attending to the "group-based protection needs of IDPs, as a separate issue from the material needs of IDPs (which may or may not vary significantly from those of nondisplaced populations)".7 This comment reminds us that just as IDPs and refugees are similar in certain respects and distinguishable in others, so too are IDPs and non-displaced civilians and, for that matter, male and female IDPs.

Some of the IDP Guiding Principles simply reiterate existing norms of international human rights and international humanitarian law, or restate them in terms directly applicable to the IDP context. Other provisions of the Guiding Principles adapt by analogy from the UN Refugee Convention and regional refugee instruments. Finally, the Guiding Principles also draw from other sources of "soft law", which often offer greater precision and detail than broadly worded norms contained in international treaties and conventions. As the annotations indicate, the content of the Guiding Principles was informed by, or is consistent with, the Convention on the Elimination of All Forms of Discrimination Against Women (CEDAW), the 1993 UN Declaration on the Elimination of Violence Against Women, the Inter-American Convention on the Prevention, Punishment and Eradication of Violence Against Women, the Statutes of the War Crimes Tribunals for the Former Yugoslavia and Rwanda and the Rome Statute for the International Criminal Court.

A thorough analysis of the IDP Guiding Principles lies beyond the scope of this paper. ${ }^{8}$ The following protection-related provisions are highlighted because of their centrality and/or because of their particular salience for women displaced by conflict:

- preclusion or minimisation of displacement through compliance with international human rights and international humanitarian law (Principle 5)

- right against arbitrary displacement (Principle 6)

- equality and non-discrimination between IDPs and non-displaced people in the enjoyment of international and domestic rights and freedoms (Principle 1; Principle 22) 
- equality and non-discrimination among IDPs in the application of the Guiding Principles; equality not violated by differential protection and assistance to vulnerable groups (including pregnant women, mothers with young children and female heads of household) (Principle 4)

- right to dignity and physical, mental and moral integrity, including protection against gender-based violence, forced prostitution, indecent assault, slavery, sale into marriage, acts of violence intended to spread terror (Principle 11)

- right to respect for family life, including entitlement of displaced family members to remain together (even in internment camps), and facilitation of reunification of separated families (Principle 17)

- entitlement to necessary medical care and attention "to the fullest extent practicable and with the least possible delay", without distinction on grounds other than medical grounds; access to psychological and social services (Principle 19.1)

- special attention to the health needs of women, including "access to female health care providers and services [and] reproductive health care, and appropriate counseling for victims of sexual and other abuses" (Principle 19.2), and to the prevention of communicable diseases, including HIV (Principle 19.3)

- equal right of women and men to obtain new or replacement identity documents from authorities, without the imposition of "unreasonable conditions, such as requiring the return to one's area of habitual residence" (Principle 20)

- special efforts to enable women and girls to exercise their right to educational and training programmes and facilities as soon as conditions permit (Principle 23)

- right to an adequate standard of living (Principle 18.1); right to seek freely opportunities for employment and to participate in economic activities (Principle 22.1(b)).

The IDP Guiding Principles encapsulate two important human rights dimensions of internal displacement: first, forcible displacement itself (where arbitrary and/or of undue duration) violates human rights, and secondly, displacement precipitates and exacerbates the violation of other fundamental human rights and protections under international humanitarian law (the laws of war).
As this abbreviated sampling above suggests, the IDP Guiding Principles are sensitive to many of the gender-specific dimensions of internal displacement, including sexual and gender-based violence; sexual, reproductive and mental health risks; food insecurity; access to education and livelihood; non-recognition of women's independent legal personality, etc. Admittedly, some of the provisions that explicitly address gender are framed in hortatory rather than mandatory terms, but it seems reasonable to suppose that the main obstacles to implementation have less to do with the precise wording of the IDP Guiding Principles than with inadequate resources, the exigencies of crisis management and perhaps political will. ${ }^{9}$

In addition to articulating and defending the specificity of internally displaced women's protection needs, the IDP Guiding Principles also encourage authorities to recognise and respect women's agency. For example, Principle 3(d) advises authorities to involve women in the planning and implementation of relocation, and Principle 18.3 similarly instructs authorities to make "special efforts" to ensure women's participation in the planning and distribution of food, shelter, clothing and medicine. Involving women in these activities may, among other things, lead to greater attention to the impact of relocation processes and camp design on women's security. ${ }^{*}$ Women's participation in the latter activities would also be instrumental in ensuring non-discriminatory distribution practices, and in diminishing the risk that male relief workers and/or male IDPs will abuse their access to basic supplies to sexually exploit female IDPs.

\section{Institutional framework}

Although primary responsibility for IDPs resides with their state of nationality, the unwillingness or inability of these states to respond effectively to the challenges of internal displacement necessitates an international response. Owing in part to the fact that IDPs are not the subject of a negotiated international agreement, IDPs are rather like institutional orphans. No single agency is dedicated to their protection and assistance. Since the early 1990s, various United Nations agencies, regional governmental agencies, the

*The location of latrines and the means of gathering firewood are two commonly cited illustrations of camp design issues that affect women's security. 
International Committee of the Red Cross (ICRC) and a host of domestic, regional and international non-governmental organisations have collaborated in addressing the humanitarian and protection needs of IDPs. This collaborative response has sometimes been criticised as inadequate, ad hoc, unaccountable and opaque. Rather than review its evolution through the years, I will briefly describe the current set of institutional arrangements. ${ }^{10-12}$

The United Nations' senior humanitarian official, the Emergency Relief Co-ordinator, bears overall responsibility for co-ordinating protection and humanitarian assistance in complex emergencies through the Office for the Coordination of Humanitarian Affairs (UNOCHA). The coordinating function is executed through the Inter-Agency Standing Committee (IASC). Members of the IASC are drawn from key humanitarian actors, and include representatives from UN agencies and international nongovernmental organisations. The role of the ICRC is especially significant in the context of armed conflict because its mandate is guided by international humanitarian law, which specifically focuses on the laws of war in relation to civilians and combatants. The IASC also has a SubWorking Group on Gender.* In addition to UN representatives, the Gender Group also includes representatives from the Red Cross, Oxfam and the Women's Commission on Refugee Women and Children. In 1999, the IASC issued a Policy Statement for the Integration of a Gender Perspective in Humanitarian Assistance. In 2005, it produced the Guidelines for Gender-Based Violence Interventions in Humanitarian Settings: Focus on Prevention of and Response to Sexual Violence in Emergencies, ${ }^{13}$ and in 2006, the IASC released Women, Girls, Boys and Men - Different Needs, Equal Opportunities, a Gender Handbook on Humanitarian Action. ${ }^{14}$

Reform of the entire humanitarian response system in 2005 resulted in the introduction of a "cluster approach". The IASC has identified nine sectors or areas of concern and created working groups for each cluster. Each working group is tasked with designating a lead agency for that cluster, developing a list of roles and responsibilities associated with the cluster and member

*Formerly the IASC Task Force on Gender and Humanitarian Assistance. agencies, and surveying existing gaps and capacities. The UNHCR is the cluster lead for protection, emergency shelter and camp co-ordination and management, which is consistent with the fact that the UNHCR has long engaged in extending its "good offices" to a segment of the world's IDP population. This means that UNHCR undertakes activities toward IDPs that are not strictly required by the UNHCR mandate. WHO has leading responsibility in the health cluster. The new cluster approach is being rolled out in emerging sites of complex emergencies and natural disasters.

A gender task force working across the clusters recently produced a Gender Handbook on Humanitarian Action. This document sets out background information and key actions regarding gender-specific dimensions for most of the nine clusters at different stages of a humanitarian emergency, thereby enabling the mainstreaming of gender issues within each sector. Humanitarian actors are optimistic about the potential of the cluster approach to provide greater effectiveness and accountability in protection and assistance.

While the UNHCR is the lead agency in the protection cluster, UNOCHA has also created an inter-agency protection capacity project (ProCap), and a gender capacity project (GenCap). ProCap's objective is to respond to urgent requirements for "rapid deployment of experienced protection staff to support the UN protection response for IDPs and other vulnerable groups in emergencies and complex crises". ${ }^{\text {*** }}$ GenCap will adapt this model

- The clusters and lead agencies for conflict-induced IDPs are as follows: Logistics (World Food Programme), Emergency Telecommunications (UNOCHA, UNICEF, WFP), Camp Co-ordination and Management (UNHCR), Emergency Shelter (UNHCR), Health (WHO), Nutrition (UNICEF), Water, Sanitation and Hygiene (UNICEF), Early Recovery (UNDP) and Protection (UNHCR).

${ }^{* *}$ According to the IASC website, the Guidelines specifically detail "minimum interventions for prevention and response to sexual violence to be undertaken in the early stages of an emergency", while the Gender Handbook "is a sector-by-sector guide on how to ensure gender equality programming in humanitarian situations. It provides practical tips on how to mainstream gender and checklists to measure the progress in meeting the needs and ensuring the equal participation of women, girls, boys and men in all aspects of humanitarian response". The Guidelines and the Handbook are meant to support and complement one another. 
by employing senior gender advisors and maintaining a roster of gender officers for rapid field deployment in order to ensure mainstreaming of gender issues in all aspects of the humanitarian response.

\section{National responses}

Implementation of the IDP Guiding Principles requires cooperation, or at least non-interference, by the state. With respect to women's human rights, achievement of protection goals before, during and post-conflict necessitates a domestic legal framework that responds to gender-based violence, affirms women's independent legal identity and devises a property regime that enables women to control property on equal terms with men.

Since 2000, over a dozen states have developed policies or laws that reflect or implement aspects of the IDP Guiding Principles, including at least some gender-related provisions. ${ }^{16 *}$ Progress in narrowing the gap between principle and practice remains a persistent problem, owing to the non-neutrality of the state vis-a-vis different classes of IDPs, direct or indirect responsibility for human rights and humanitarian law violations, resource limitations, and the pervasive, systemic inequality of women. The following snapshots illustrate some of the challenges and achievements.

Property law regimes play a crucial role in determining whether single and widowed women are able to thrive upon post-conflict return or resettlement. In Rwanda, local law precluded widowed women from inheriting property from their husbands or parents. In Liberia, in response to advocacy by local women's organisations on this restriction, Liberian law was recently amended to enable women married under customary law to inherit property from their spouses.

\footnotetext{
*States and regional organisations that have adopted or indicated an intention to adopt laws or policies reflecting the Guiding Principles include: Angola, Burundi, Liberia, Sierra Leone, Nigeria, Uganda, Great Lakes Region, India, Nepal, Philippines, Sri Lanka, Colombia, Peru, Azerbaijan, Bosnia-Herzegovina, Georgia, SerbiaMontenegro, Russia, Turkey, the African Union, the Intergovernmental Authority on Development in the Horn of Africa, the Organization of American States, and the Organization for Security and Cooperation in Europe. ${ }^{16}$
}

However, effectively disseminating the fact and significance of the amendments, especially to internally displaced women, remains a challenge. ${ }^{17}$

In 2004, the Colombian Constitutional Court ruled that state authorities were violating the constitutional rights of IDPs: "through action or omission by the authorities in providing displaced populations with optimum and effective protections, thousands of people suffer multiple and continuous violations of their human rights". ${ }^{18}$ The Court drew particular attention to the high proportion of vulnerable social groups (including female heads of household and pregnant women) among the IDPs.

In Darfur, the protection mandate of international actors is hampered by the antagonistic stance of the government of Sudan. Abduction and rape by militia is recognised as chronic and widespread, especially when women leave the camp to collect firewood. Nevertheless, some organisations have withdrawn from programmes directed at access to justice for victims in order not to incite further resistance from the Khartoum government. Community-level initiatives to protect women and girls, such as organising patrols when women collect firewood, have met with supportive but inconsistent collaboration from humanitarian agencies. Similarly, the introduction of fuel-efficient stoves that use less firewood has been hampered and delayed by internal debate within humanitarian organisations about the impact on the livelihood of women who collect firewood to earn income. ${ }^{19}$

Internally displaced women in Darfur may also be vulnerable to reprisal from members of their own community, especially when they engage collectively in protection activities that appear to challenge conventional gender hierarchies. International organisations generally lack the capacity to protect local organisations from these heightened threats. On the other hand, success in suspending a Sudanese legal requirement of reporting sexual violence to local police as a prerequisite to medical treatment, and the successful conviction of an army officer for rape, can be counted as important achievements. ${ }^{16}$

\section{Refugees}

The contemporary refugee regime began in Europe, and was formulated for Europeans displaced by World War II and the descent of the 
Iron Curtain. The singular, distinctive right that attaches to the declaration of refugee status is non-refoulement, or non-return to the country of nationality. The 1951 UN Convention Relating to the Status of Refugees formally expanded in geographical, temporal scope with the 1967 Protocol on the Status of Refugees, but the legal definition of the refugee remains essentially unchanged. A refugee is a person who:

"...owing to a well-founded fear of being persecuted for reasons of race, religion, nationality, membership of a particular social group, or political opinion, is outside the country of his nationality, and is unable to or, owing to such fear, is unwilling to avail himself of the protection of that country." 20

Refugees must be outside their country of citizenship, must fear a harm that constitutes persecution, and the persecution must have a nexus to race, religion, nationality, membership in a particular social group or political opinion. The 1984 Organization of American States (OAS) Cartagena Declaration and the 1969 Organization of African Unity (now African Union) Refugee Convention broaden the scope of refugee protection, de-emphasise the individualised requirement of persecution, and encompass reasons for flight that affect populations as a whole, such as "generalised violence", "massive violation of human rights", and events "seriously disturbing public order".21,22

The mandate of the UNHCR is "to safeguard the rights and well-being of refugees. UNHCR strives to ensure that everyone can exercise the right to seek asylum and find safe refuge in another state, and to return home voluntarily."23 To that end, the UNHCR engages in protection and humanitarian assistance, works with states that host asylum seekers and refugees, and seeks durable solutions to refugees' displacement, whether by return, local integration in the country of first asylum, or resettlement in another country.

In addition to serving those who meet the legal definition of a refugee, the UNHCR also responds to situations of mass influx by designating groups as "prima-facie refugees" without performing individualised assessments. The UNHCR also lends its "good offices" to assisting some IDPs and stateless people. To the extent that the mandate of the UNHCR and the International Red Cross overlap, the division of labour tends to favour the UNHCR in the refugee domain, unless host governments actively impede UN agencies from operating in the field. ${ }^{24,25}$

Factoring gender and sexuality into the refugee regime

Gender emerged on the international refugee agenda in the mid-1980s, and attention at the international, regional and domestic level has been manifested in a number of initiatives since then. Indeed, during a period that witnessed states (especially in the global North) expending increasing resources on non-entrée mechanisms to deter and deflect asylum-seekers, the generally favourable response (in principle) to recognising gender-related persecution stands out as a rare counter-trend, thanks in large measure to feminist advocacy, scholarly research and networking inside and outside government.

Reference to sex or gender is notably absent from the grounds of persecution, leading some to insist that the existing definition of a refugee must be amended to add sex or gender to the list. This argument has not prevailed internationally or domestically for a variety of reasons, not least of which is that the prospect of inviting states to open up the refugee definition for revision in a climate of resistance (if not open hostility) to refugees risks the outcome of a more restrictive, retrograde definition.

Instead, the UNHCR and various states have adopted guidelines that advance a gendersensitive interpretation of the existing refugee definition. The guidelines counsel decisionmakers on procedural issues that relate to creating a safe and supportive environment within which a refugee claimant can disclose her narrative in furtherance of a proper determination of refugee status. This approach has been refined over the years through the individual initiatives of states, NGOs, regional organisations and the UNHCR. ${ }^{26-28}$ Each set of guidelines draws inspiration from existing refugee jurisprudence in non-gender contexts, developments in women's human rights and precedents from other jurisdictions. The outcomes reflect an ongoing process of iteration, mutual feedback and transnational networking across jurisdictions and subject areas.

Broadly speaking, the substantive analysis contained in most gender guidelines addresses 
three elements of the refugee definition: the agent of persecution, the form of persecution and the reasons for persecution. Drawing on feminist critique of the public/private distinction as well as developments in refugee jurisprudence, gender guidelines emphasise that the agent of persecution may be the state, or a nonstate actor (spouse, relative, employer, insurgent group) in circumstances where the state is unable or unwilling to provide protection. In addition to forms of physical and psychological suffering commonly inflicted on both sexes, persecution includes rape, domestic violence, female genital mutilation and dowry-related violence and trafficking. Although refugee law distinguishes between prosecution and persecution, the enforcement of certain laws (e.g. forced abortion) may be inherently persecutory, even if in furtherance of a legitimate state objective (population policy). The same applies to laws imposing a penalty that is seriously disproportionate to its objective (e.g. stoning for adultery). The cumulative effect of persistent, chronic discrimination that imposes consequences "of a substantially prejudicial nature on the person concerned" may also constitute persecution. Similarly, a pattern of state denial of protection to women abused by non-state actors could also contribute to a finding of persecution. ${ }^{29}$

While the form of persecution may be uniquely or mainly inflicted on women, the reasons may reflect complex intersections between gender and race or other bases of discrimination, exclusion or violence. For example, women may be subject to sexual violence or reproductive control to terrorise, punish or annihilate the racial, ethnic or cultural group to which they belong. In such cases, persecution may be gendered in form, but on account of race or nationality. $A$ union organiser may be raped on account of real or imputed political opinion, while her male colleague may be tortured in some other way or subjected to sexual violence as well. ${ }^{30}$ Women who resist the strictures placed on them by theocratic regimes in the name of religion may face persecution on account of their actual or imputed

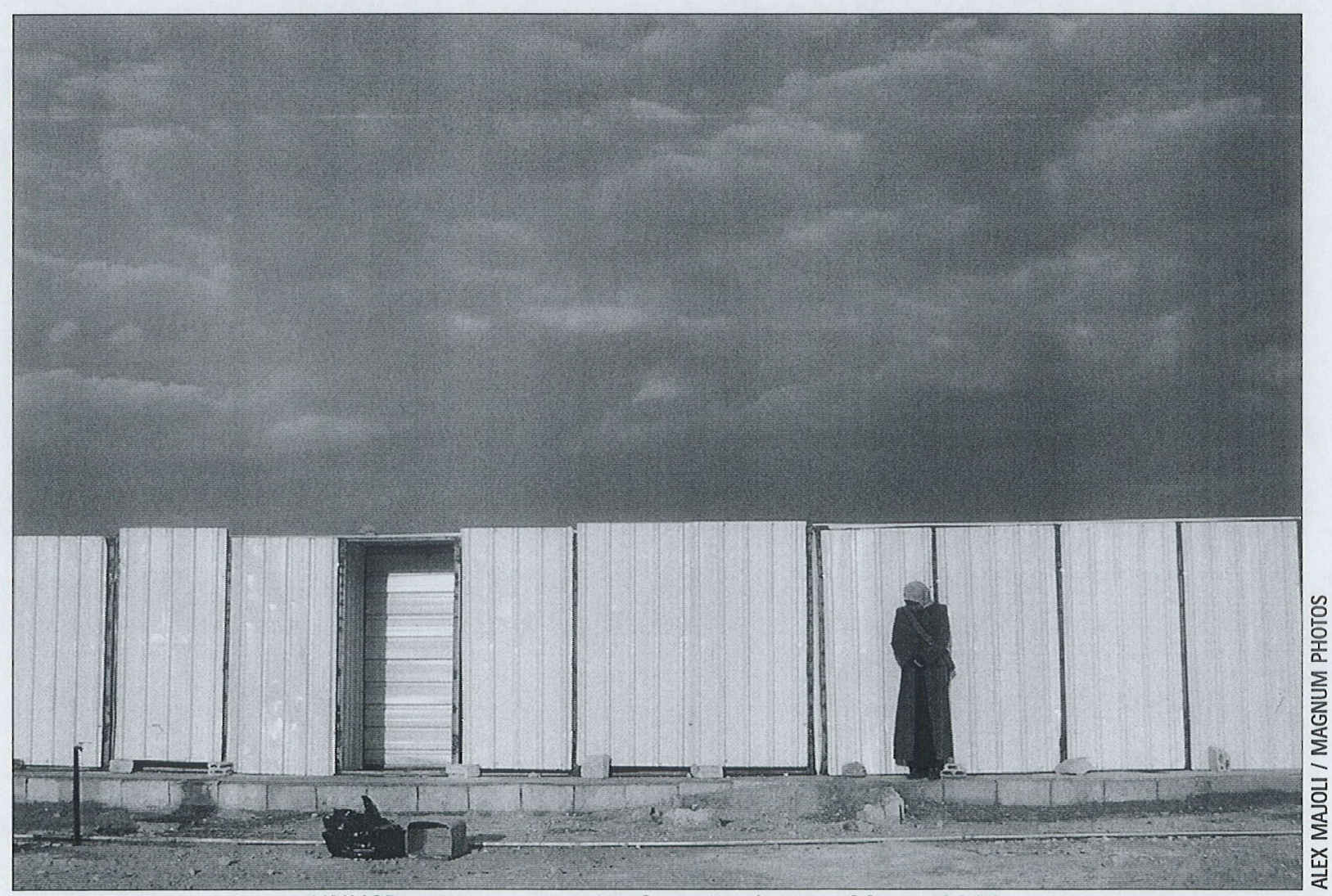

UNHCR refugee camp for Somalis, Jordan, March 2003 
political opinion (feminism) or religion (nonconformity to dominant interpretation of religion). The persecution may be precipitated by non-conformist conduct, such as manner of dress, or the expression of views. In certain cases, the reason for persecution and/or the absence of state protection is the devalued status of women. Domestic violence and female genital mutilation are two frequently cited examples. Defining and circumscribing "particular social group" in refugee law has proven controversial, but tribunals and courts in various jurisdictions have nonetheless accepted that women (or some subset thereof) may constitute a particular social group because sex is an innate or unchangeable characteristic, and women are socially subordinate to men.

As the foregoing examples illustrate, the grounds of persecution may overlap, and the same facts may yield multiple (though complementary) legal conclusions regarding the nexus between persecution and the listed grounds. Some states, courts and the UNHCR have explicitly confirmed that gays, lesbians, bisexuals and other sexual minorities may also constitute particular social groups.

On the procedural side, gender guidelines offer practical advice on how to promote an adjudicatory environment that is non-intimidating, accessible, culturally sensitive, confidential and female-only (on request or automatically). Gender guidelines may also caution decision-makers about inappropriate reliance on demeanour and the possible dearth of documentary evidence. The UNHCR guidelines counsel that female asylum seekers should be interviewed separately and in the absence of male kin in order to protect women's opportunity to present their own case, and that psycho-social counselling and other support be available where necessary.

Fewer than half of asylum-seekers are women. Taking as given the estimates that women comprise more than half the world's refugees, this suggests that asylum is less accessible for women than men. Since countries in the global North (including Australia) expend enormous resources on deterring the arrival of asylum-seekers, thereby rendering the journey expensive, dangerous and difficult, it is unsurprising that proportionally fewer women are in a position to reach countries of asylum. Practices of detention, immiseration (through denial of access to work, housing or subsistence), low asylum acceptance rates and intensified efforts to deport, detrimentally affect all asylum seekers. Women, especially those with children, become easy targets for the enforcement action by immigration officials. Thus, the success of gender guidelines in encouraging greater recognition of gender-related persecution must be balanced against the fact that fewer women than ever are able to access countries of asylum to advance those refugee claims.

\section{Conclusion}

A survey of the many guidelines, handbooks, resolutions, toolkits, conclusions and manuals produced by various UN bodies confirms an awareness of the protection issues specific to women and girls displaced by conflict, and an intention to operationalise the norms at all levels, especially in the field. Persistent challenges to effective implementation remain; the reasons for the gap between theory and practice are diverse, complex, institutional and logistical. Finding ways to bridge the two is both an incremental and an iterative process.

Having said that, I wish to close by identifying two dimensions of conflict-related displacement that are under-addressed by the current institutional divisions of labour and allocation of mandates within the UN. The first is protracted displacement. The main UN bodies that address displacement (UNHCR and UNOCHA) operate from the institutional premise that displacement is and will be temporary. Yet in 2006, the average duration of residence in a refugee camp was 17 years. ${ }^{31}$ This institutional commitment to the temporariness of displacment constrains the capacity of UNHCR and UNOCHA to adopt strategies that accommodate the growing permanence of the temporary. There is an acknowledged but unaddressed need to formulate long-term programming in the domains of health, shelter, income generation and livelihood. Confronting the potential permanence of the temporary probably requires strategies that, among other things, traverse the divide between displaced women and girls and non-displaced women and girls in surrounding communities.

Literal and legal literacy is also critical to supporting and enhancing women's agency. Women need to know their rights under inter- 
national and domestic law. International and national actors have demonstrated the limitations of their willingness or ability to protect the rights of women and girls. The capacity of women and girls to advocate on their own behalf and to engage in formulating and implementing strategies for self-protection and survival can only be expanded with knowledge. Increased legal literacy may also enhance the nature and quality of the collaboration between displaced women and girls and the international organisations (governmental and non-governmental) who support them.

\section{Acknowledgments}

This article is drawn from "Legal Aspects of Conflict Induced Migration by Women", a report first prepared for UNFPA. The author thanks UNFPA, and Sahir Abdel Hadi and John Tirman, for their support.

\section{References}

1. Martin S. Refugee Women, 2nd ed. Lanham7 Lexington Books, 2003.

2. Convention against Torture and Other Cruel, Inhuman or Degrading Treatment or Punishment, G.A. res. 39/46, annex, 39 U.N. GAOR Supp. (No. 51) at 197, U.N. Doc. A/39/51 (1984), entered into force June 26, 1987. Geneva: United Nations, 1984.

3. United Nations Security Council Res. 1325 (2000), adopted by the Security Council at its $4213^{\text {th }}$ meeting, 31 October 2000. At: bwww.un.org/events/ res_1325e.pdf N.

4. UNHCR Executive Committee. Issues Related to Women at Risk: Discussion Paper on a Possible Executive Committee Conclusion on Displaced Women and Girls at Risk. EC/57/ SC/CRP.7. Geneva: United Nations, 17 February 2006. At: bwww.unhcr.org/excom/ EXCOM/43f5f5f92.pdf N.

5. Guiding Principles on Internal Displacement. U.N. Doc. E/CN.4/ 1998/53/Add.2 (1998), noted in Comm. Hum. Rts. res. 1998/50.

6. Cohen R, Deng F. Masses in Flight: The Global Crisis of Internal Displacement. Washington? Brookings Institution Press, 1998.

7. Collinson S. Lessons learned from specific emergency situations: a synthesis. In: Castles, et al. Developing DFID's Policy Approach to Refugees and Internally Displaced Persons.
Volume II: Commissioned Papers. February 2005. At: bwww.rsc.ox. ac.uk/PDFs/ Policy\%20Approaches\%20to\% 20Refugees\%20and\%20IDPs\% 20RSC-DFID\%20Vol\%20II.pdf N.

8. KalRn W. Guiding Principles on Internal Displacement: Annotations, Studies in Transnational Legal Policy, No.32. Washington DC7 American Society of International Law and the Brookings Institution Project on Internal Displacement, 1999.

9. Bagshaw S, Paul D. Protect or Neglect: Toward a More Effective United Nations Approach to the Protection of Internally Displaced Persons. Brookings-SAIS Project on Internal Displacement, UN OCHA, 2004.

10. Feller E. UNHCR's role in IDP protection: opportunities and challenges. Special Issue: Putting IDPs on the Map. Forced Migration Review 2006; December:11 .

11. McNamara D. Humanitarian reform and new institutional responses. Special Issue: Putting IDPs on the Map. Forced Migration Review 2006; December:9.

12. Morris T. UNHCR, IDPs and clusters. Forced Migration Review 2006;25:54.

13. Inter-Agency Steering Committee. Guidelines for Gender-Based Interventions in Humanitarian Settings:
Focusing on Prevention and Response to Sexual Violence. September 2005. At: bwww. humanitarianinfo.org/iasc/ content/products/docs/tfgender_ GBVGuidelines2005.pdf N.

14. Inter-Agency Steering Committee. Women, Girls, Boys and Men - Different Needs, Equal Opportunities, a Gender Handbook on Humanitarian Action. December 2006. At: bwww.humanitarianinfo.org/ iasc/content/documents/default. asp?doclD=1948\&publish $=0 \mathrm{~N}$.

15. Providing capacity to do protection: ProCap. Special Issue: Putting IDPs on the Map. Forced Migration Review 2006;December:14.

16. Brookings Institution. National and Regional Laws and Policies on Internal Displacement (undated). At: bwww.brook.edu/ $\mathrm{fp} /$ projects/idp/idp_policies.htmN. Accessed 21 February 2007.

17. Mooney E. Prioritizing Protection and Assistance for Africa's Internally Displaced Women and Children, Brooking's Institution, 26 May 2004. At: bwww.brookings.edu/ fp/projects/idp/20042605mooney. htm-71k-2004-05-26 N.

18. Cepeda-Espinosa MJ. How far may Colombia's Constitutional Court go to protect IDP rights? Special Issue: Putting IDPs on the Map. Forced Migration Review 2006;December:21-2.

19. Pantuliano $S, O^{\prime}$ Callaghan $S$. The protection crisis:a review of 
field-based strategies for protection in Darfur. Humanitarian Policy Group Discussion Paper. Overseas Development Institute, December 2006.

20. Convention relating to the Status of Refugees, 28 July 1951, 189 U.N.T.S. 2545 (entered into force 22 April 1954), supplemented by the Protocol relating to the Status of Refugees, 606 U.N.T.S. 8791 (entered into force 4 October 1967). Geneva: United Nations 1951.

21. Cartagena Declaration on Refugees, Nov. 22, 1984, Annual Report of the Inter-American Commission on Human Rights, OAS Doc. OEA/Ser.L/V/II.66/ doc. 10 , rev. 1, at 190-93 (1984-85).

22. Convention Governing the Specific Aspects of Refugee Problems in Africa, 1001
U.N.T.S. 45 , entered into force June 20, 1974.

23. UNHCR. Mission Statement. UNHCR Global Appeal 2007. Geneva: 2007. At: bwww.unhcr.org/publ/PUBL/ 4565a5742.pdf N.

24. Aeschlimann A. Protection of IDPs: an ICRC view. Forced Migration Review 2006; October(IDP Supplement):25.

25. Krill F. The ICRC's policy on refugees and internally displaced persons. International Review of the Red Cross 2001; 83:607.

26. Center for Refugee and Gender Studies, Scholarly Articles (bibliography). At: bhttp://cgrs.uchastings.edu/ law/articles.phpN.

27. Center for Refugee and Gender Studies, Gender Guidelines (Australia, Canada, EU, Ireland, Netherlands, Norway, South Africa, Sweden, UK, US). At: bhttp://cgrs.uchastings.edu/ law/gender_guidelines.phpN.

28. UNHCR Executive Committee (ExCom), Conclusion on Women and Girls at Risk No. 105 (LVI) - 2006, 6 November 2006

29. UNHCR. Guidelines on International Protection: Gender-Related Persecution within the context of Article 1A(2) of the 1951 Convention and/or its 1967 Protocol relating to the Status of Refugees, HCR/GIP/02/01, 7 May 2002.

30. Oosterhoff $P$, Zwanikken $P$, Ketting E. Sexual torture of men in Croatia and other conflict situations: an open secret. Reproductive Health Matters 2004;12(23):68-77.

31. United Nations Population Fund. State of World Population 2006: A Passage to Hope, Women and International Migration. New York7 UNFPA, 2006.
Résumé

Cet article passe en revue les cadres juridiques internationaux, notamment les nombreux guides, manuels, instruments, directives, résolutions et conclusions préparés par plusieurs institutions des Nations Unies, qui confirment la prise de conscience des problèmes de protection propres aux femmes et aux filles déplacées par les conflits. II se demande dans quelle mesure ces documents abordent les conséquences pour les femmes de la migration induite par les conflits ainsi que le rôle des Nations Unies comme organisations gouvernementales internationales dans I'application de ces normes. L'accent est mis sur les femmes déplacées à l'intérieur de leur pays et les femmes réfugiées. Outre les difficultés à faire respecter les directives existantes, l'article conclut que deux domaines d'intervention exigent beaucoup plus d'attention des organisations internationales gouvernementales et non gouvernementales : définir des stratégies tenant compte des réalités du déplacement à long terme, voire permanent, et favoriser I'alphabétisation des femmes et les familiariser avec les normes juridiques.
Resumen

En este artículo se examinan los marcos jurídicos internacionales, incluidas las numerosas directrices, guías, resoluciones, herramientas, conclusiones y manuales producidos por diversos organismos de las Naciones Unidas, que confirman conocimiento de los aspectos de protección específicos a las mujeres y niñas desplazadas por conflicto. Se explora hasta qué punto estos documentos tratan el impacto en género de la migración inducida por conflicto y la función de los organismos de la $\mathrm{ONU}$ como organizaciones gubernamentales internacionales en la aplicación de estas normas. Se centra en las mujeres desplazadas internamente y en mujeres refugiadas. Además de los problemas en hacer cumplir las directrices establecidas, el artículo concluye que dos áreas - elaborar estrategias que tomen en cuenta las realidades del desplazamiento a largo plazo, incluso permanente, y mejorar el alfabetismo literal y jurídico de las mujeres requieren mucha más atención por parte de las organizaciones internacionales gubernamentales y no gubernamentales. 